\title{
ON OPTIMIZATION OF THE PID GOVERNOR FOR DIESEL ENGINE
}

\author{
D.N. MALKHEDE, H.C. DHARIWAL and M.C. JOSHI \\ Department of Mechanical Engineering \\ Indian Institute of Technology \\ Powai, Bombay-400 076, India \\ E-mail: hcd@me.iitb.ac.in
}

Received July, 24, 2001

\begin{abstract}
In a diesel engine, governor is indispensable for ensuring that the engine maintains a certain speed under various load conditions, that the engine speed does not exceed a certain speed as a protection against self-destruction or stall. Also, speed fluctuations resulting from poor governing, lead to vibrations, noise, wear and tear and increased level of soot. Therefore it is desirable to have minimum speed fluctuations under all engine-operating conditions. Inspite of many limitations, most of the existing engines still use simple mechanical governor providing proportional control only. Electronic governors can provide a more flexible $P$ (proportional), $I$ (integral), and $D$ (derivative) control under all speeds and loads. So far no work is reported on optimizing the controller parameters using the analytical approach. In the present work turbo charged diesel engine is analytically modeled based on Krutov's approach for the control analysis. Attempts have been made to optimize controller parameters. The criterion for minimizing the engine speed fluctuations is met by minimizing the Integral Squared Error in engine speed. The parameters obtained have been used to study the engine speed response. The results have shown remarkable improvement in the engine speed fluctuations.
\end{abstract}

\section{INTRODUCTION}

Diesel engines have established themselves in all heavy duty applications due to their high fuel economy, better part load performance and most importantly, the reliability. Diesel engines are extensively used in transportation, electric power generation, earth moving equipments etc. In most of these applications, engines operate at varying speeds and loads under wide range of ambient conditions. The fluctuations in load cause fluctuations in engine speed, which cause harm to the engine, like increasing emissions, wear and 
tear of the engine, giving rise to dangerous vibrations, decreasing fuel economy and engine life etc. The drivability and comfortability of the vehicle are severely affected. The diesel engines should therefore be equipped with a governor that will limit the variation in speed.

Automatic speed control of diesel engines has long relied on the conventional mechanical and hydraulic governors. These conventional mechanical governors are found to be inefficient in controlling speed [2]. Further, the use of turbocharging and the turbocharger lag in diesel engine makes the system complex with so many parts interacting with each other due to which conventional governors are unable to handle such a system efficiently. There are other factors like, change in engine characteristics due to aging, change in ambient conditions, change in fuel properties etc. which the conventional governors can not take into account to control the engine efficiently. Increasingly, therefore, governors are being required to perform auxiliary control functions. This, combined with tightening legislative restrictions on the exhaust emissions and performance specifications have led to a change from mechanical to electronic control.

Electronic governors can control and monitor number of parameters with better stability and dynamic behavior. Additionally, the electronic control has advantages of speed of response, freedom from friction and wear, ease of installation, convenience of adjustment and setting up.

The model used based on Krutov's approach in this study is based on the mean values of the engine variables. This model along with the PID controller law are then used to obtain the function for the speed error, $N_{e}$. The equation obtained is in terms of the controller parameters $k_{p}, k_{i}, k_{d}$ and t. The values of the controller gains $k_{p}, k_{i}$ and $k_{d}$ are obtained by minimizing the Integral Squared Error of Diesel Engine Speed $N_{e}$ using the software Mathematica. The resulting values of the controller parameters are used to study the engine speed response. The engine speed response is obtained by solving the model equations by Runge-Kutta method using MATLAB. The result obtained here have shown a significant improvement over the previous study $[8 ; 10 ; 11]$.

\section{LITERATURE REVIEW}

Many attempts have been made in the past years to understand the transient response of turbo-charged diesel engine behavior in order to apply the control engineering concepts and improve the performance of the engine system.

Pioneering work on the transient response analysis of TC diesel engine has been carried out at the University of Manchester Institute of Science and Technology (UMIST), by Winterbone et al [12; 17]. It has been stated that the main reason for poor transient performance of the engine lies in the TC lag. Due to large time lag, the TC is not able to supply sufficient air to the engine during rapid load variations. The large time delays in the engine air path are caused due to high inertia of TC and big volume of the inlet and exhaust manifolds. 
Winterbone et al $[12 ; 17]$ have suggested external means to accelerate the compressor through air injection or by, additionally fitting a pelton wheel to the compressor shaft. Alternatively, Krutov [8] in another notable work suggests direct injection of supplementary air into the inlet manifold of the engine.

Failure in providing mathematical solution to this problem can be attributed to large number of variables of the engine and that of loads as well, to which these engines are subjected. Different modeling approaches like, quasi-steady, mean value, wave action, non-linear, thermodynamic and block diagram models are discussed in literature. These models predict the trends of system behavior over the operating range of the engines, both under steady state and dynamic conditions. The different models and their practicality is discussed briefly.

Quasi-Steady Models are based on the steady-state characteristics of all the components, viz the compressor, the turbine and the engine and the basic laws of mechanics and thermodynamics.

San-Chin Tsai et al [13] developed a quasi-linear dynamic model for turbocharged diesel engine based on local linearization. These locally linearized models have the advantage of simplicity and short runtime, such that, real time simulation may be possible.

Mean Value Models are based on mixture of relationships derived from the first principles and empirical correlations [12]. The time scale in such models ignores individual events to maintain simplicity. In a mean value engine model, the engine will be built-up from a series of components which can be tested and validated individually. The mean value models are relatively easy to configure and can be made to run quickly on special purpose hardwares. However, their precision ultimately depends upon the kind of physical relationships they represent, as they are based on empirical correlations and simple physical formulae.

Wholly Dynamic Models have been described in detail by Winterbone et al [17], where step tests were used as a transfer function identification technique. The model is based on the filling and emptying method of evaluating engine performance and includes turbine and compressor characteristics and a generator model. The filling and emptying technique is simply the application of the unsteady flow version of the first law of thermodynamics to the various volumes in the overall system.

Non Linear Models are used for detailed diagnosis of an engine for the whole range of speed and load including the transient of the engine. Due to rapid advances of computer technology more complicated non linear controller algorithms are possible for implementation on the engine.

A nonlinear mathematical model has been developed by Neil Watson [14], [15] to predict the transient response of a turbocharged diesel engine. The effects of using a fuel pump rack limiter and that of re-matching the turbocharger in conjunction with an exhaust waste gate are presented.

Block Diagram type of Modeling for speed control analysis, the dynamic 
relationship between fuel input and torque or speed of the engine is inevitable. Block diagram type of modeling is one type of modeling which gives such a relationship and which is of primary importance for speed control analysis. These models are based on filling and emptying technique and include the various characteristics of the engine components.

Block diagram type of modeling used in literature can be broadly divided into experimental and analytical block diagram type of modeling.

Thiruarooran et al [12] describe a method, which is based on correlation techniques to extract linear transfer function model from a wholly dynamic non-linear engine model. Yousif Ali El-Imam [3] has used experimental block diagram modeling approach for simulating high adaptive speed regulator system for diesel engines. Jaliwala et al [6] have investigated the possibility of governing a Cummins TC diesel engine by load feedback, in addition to normal speed feedback.

One major disadvantage of the above-described models is that they generally represent engine as a black box. Analysis is done using transfer functions, obtained through experiments, at the particular working conditions they want to simulate. Since they use the characteristics of various components of a particular engine, the effect of design changes in the engine components cannot be investigated by using these models and the simulation is always specific to a particular engine and working condition.

Krutov [9] has presented analytical block diagram type of modeling to present engine-governor-load system. The design parameters of the engine have been considered and various methods of modern control design have been lucidly explained.

Chittawadgi [2] et al have shown on the basis of the analysis of Krutov's model and various dynamic characteristics of diesel engine working under transient loading conditions that PID governor based on microprocessor technology can only provide the minimum fluctuations of speed of diesel engine and best all-round performance under various conditions of working.

It has been proposed to use models based on sample data et al have shown on the basis of the analysis of Krutov's model and various dynamic characteristics of diesel engine working under transient loading conditions that PID governor based on microprocessor technology can only provide the minimum fluctuations of speed of diesel engine and best all-round performance under various conditions of working.

It has been proposed to use models based on sample data [4], since the diesel engine operation is of discrete nature. However Woodward [18] stated that speed governing in particular is based on the average values of the parameters and not on their instantaneous values.

Several attempts have been made to synthesize optimal controllers for diesel engines. Optimal control for a diesel engine speed governing loop has been formulated in [7]. Both four cylinder and six cylinder engines have been considered. A sample data model of the engine is first constructed in the state-space form. The cost function is then defined as a quadratic function of 
the error in the engine speed variables, control effort and the air fuel ratio. The optimal control problem is then solved by both dynamic programming and a discrete minimum principle. In an another effort [5] a novel smoke sensor has been used in conjunction with a tachogenerator to control the transient response of a diesel engine. The control algorithm is of proportional and Integral (PI) type. The controller parameters are chosen such that the engine overshoot and the amount of engine exhaust smoke are minimized.

In a novel smoke sensor has been used in conjunction with a tachogenerator to control the transient response of a diesel engine. The control algorithm is of proportional and Integral ( [7] small diesel engine was analyzed with speed control being the primary objective of the controller design. Engine transfer function model was developed using experimental identification technique. It is emphasized that since the diesel engines are highly nonlinear systems, an optimal controller designed for one operating condition may not work well at the other condition. One solution to such a problem is to design a robust controller which performs reasonably well for all engine operating conditions. Because of the very large variation of the engine dynamics at different speeds and power outputs, such a robust controller can never be optimal for all operating conditions. Method adopted to overcome the problem is to divide the range of the engine operation into several different zones according to engine speed and power output. An optimal controller is then designed for the engine operating in each of these zones. During the course of engine operation most appropriate controller can be employed on the basis of the engine operating condition prevailing at the moment.

Author divided the engine operating condition into 15 different zones and PID controller parameters $k_{p}, k_{i}$ and $k_{d}$ are obtained by minimizing the Integral Squared Error (ISE) of the engine speed error signal subject to step input.

Urs Christen et al [1] have presented a parallel study of two types of models, one the time based model and other the event based model. Both models are validated for its computational complexity and accuracy. Author reports that the designer would prefer to have both models available for controller design, using the time based for engine speed control and event based for the control involving flows e.g. EGR control or coordinated VGT and EGR control.

In order to design a PID controller, Sinha [11] used transfer function analysis for simulation using the model based on the Krutov approach. The results obtained by him are the engine speed responses using PID coefficients of 5, 10, 10. The work does not throw any light on the selection of these parameters.

Mruthunjaya et al [10] has simulated the same engine by Runge-Kutta method taking the non-linearity of the engine into consideration using Krutov's approach. It was shown that the model based on Krutov's approach and Runge-Kutta method of solution of model equation provides a very accurate prediction of impulse response in comparison to the experimental one. The authors have used PID controller can provide the best control to the engine governing system. Mruthunjaya has suggested some optimum values of the 


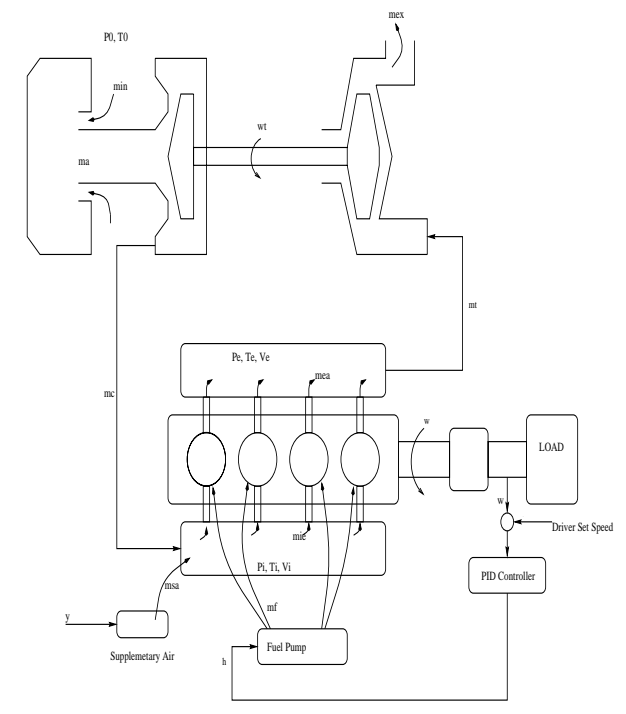

Figure 1. Engine layout showing main components of a turbocharged diesel engine with the nomenclature

PID coefficients. However the tuning of these parameters was based on the trial and error basis and not using any mathematical approach. Further work in this series [8] has adopted the optimization technique to minimize the cost function. However the optimization was done at a fixed instant of time $t$. although this also proved to reduce speed fluctuations compared to previous studies.

Present study uses time based analytically derived model based on Krutov's approach. The objective function is derived by simplifying the above model by neglecting the manifold volumes of the engine. The objective function for the engine speed feedback error $N_{e}$ is used to obtain PID controller gains $k_{p}, k_{i}$ and $k_{d}$ by minimizing its Integral Square. The parameters thus obtained are then used to study the variation of the speed fluctuations with time. This speed response is obtained by solving the model equations by Runge-Kutta method. Detailed methodology is explained in the subsequent sections of the paper.

\section{MATHEMATICAL MODEL}

Fig. 1 shows the various parts of the turbocharged diesel engine with the controller. The engine is suitably divided into four major components. The equations for these four parts are derived based on Krutov's approach [9] by applying simple physical principles such as ideal gas equation, law of conservation of mass etc. 


\subsection{The Prime Mover (Engine)}

Load torque $T_{l}$ depends on angular velocity $\omega$ and load setting $\phi$, i.e.,

$$
T_{l}=f(\omega, \phi)
$$

Similarly, the engine torque depends upon rack position (fuel supply) $h$, angular speed $\omega$ and boost pressure $p_{i}$ i.e.,

$$
T_{e}=f\left(h, \omega, p_{i}\right)
$$

The final equation for the prime mover is obtained as given below. Reader may refer $[9 ; 10]$ for further details on modeling.

$$
\tau_{e} \frac{d N_{e}}{d t}+k_{e} N_{e}=R+a_{1} P_{i n}-b_{1} L
$$

where $\tau_{e}=J_{e}\left(\frac{\delta T_{e}}{\delta h}\right)^{-1} \frac{\omega_{o}}{h_{o}}, \quad k_{e}=F_{e}\left(\frac{\delta T_{e}}{\delta h}\right)^{-1} \frac{\omega_{0}}{h_{0}}$,

$$
a_{1}=\frac{\delta T_{e}}{\delta p_{i}}\left(\frac{\delta T_{e}}{\delta h}\right)^{-1} \frac{p_{i}}{h_{0}}, \quad b_{1}=\frac{\delta T_{l}}{\delta \phi}\left(\frac{\delta T_{e}}{\delta h}\right)^{-1} \frac{\phi_{0}}{h_{0}} .
$$

To facilitate the analysis of dynamic properties of engine and its components the following dimensionless parameters have been used:

$$
N_{e}=\Delta \omega / \omega_{o} ; R=\Delta h / h_{o} ; P_{\text {in }}=\Delta p_{i} / p_{i o} ; L=\Delta \phi / \phi_{o}
$$

\subsection{The turbo-charger}

While deriving the equation for the turbocharger, the compressor torque is considered the function of boost pressure $p_{i}$ and angular speed $\omega_{t}$. Also, turbine torque depends upon the pressure in the exhaust manifold $p_{e}$, rack position $h$, and the rotor speed $\omega_{t}$, i.e.,

$$
T_{c}=f\left(p_{i}, \omega_{t}\right), T_{t}=f\left(p_{e}, h, \omega_{t}\right)
$$

Using the similar approach as that of the prime-mover equation, final turbocharger equation is obtained as,

$$
\tau_{t} \frac{d N_{t}}{d t}+k_{t} N_{t}=P_{e x}+b_{2} R-a_{2} P_{i n}
$$

$$
\begin{aligned}
\text { where } \tau_{t} & =J_{t}\left(\frac{\delta T_{t}}{\delta p_{e}}\right)^{-1} \frac{\omega_{t 0}}{p_{e 0}}, & k_{t} & =F_{t}\left(\frac{\delta T_{t}}{\delta p_{e}}\right)^{-1} \frac{\omega_{t 0}}{p_{e 0}} \\
b_{2} & =\frac{\delta T_{t}}{\delta h}\left(\frac{\delta T_{t}}{\delta p_{e}}\right)^{-1} \frac{h_{0}}{p_{e 0}}, & a_{2} & =\frac{\delta T_{t}}{\delta p_{i}}\left(\frac{\delta T_{t}}{\delta p_{e}}\right)^{-1} \frac{p_{i 0}}{p_{e 0}} .
\end{aligned}
$$




\subsection{Intake manifold}

Following dependence is assumed for the derivation,

$$
m_{i e}=f\left(p_{i}, \omega\right), \quad m_{c}=f\left(p_{i}, \omega_{t}\right), \quad m_{s a}=f(y) .
$$

Final equation for the inlet manifold is obtained from the above equations

$$
\tau_{i n} \frac{d p_{i}}{d t}+k_{i n} P_{i n}=N_{t}+b_{3} Y_{s} a_{3} N_{e}
$$

where, $\quad \tau_{i n}=\frac{v_{i}}{R_{a} T_{i}} \frac{\omega_{t}}{m_{c}} \frac{p_{i o}}{\omega_{t o}}, \quad k_{i n}=F_{i n}\left(\frac{\delta m_{c}}{\delta \omega_{t}}\right)^{-1} \frac{p_{i o}}{\omega_{t o}}$,

$$
a_{3}=\frac{\delta m_{i e}}{\delta \omega}\left(\frac{\delta m_{c}}{\delta \omega_{t}}\right)^{-1} \frac{\omega_{o}}{\omega_{t o}}, \quad b_{3}=\frac{\delta m_{s a}}{\delta y}\left(\frac{\delta m_{c}}{\delta \omega_{t}}\right)^{-1} \frac{y_{o}}{\omega_{t o}} \text {. }
$$

\subsection{Exhaust manifold}

Let consider the dependence as

$$
m_{e e}=f\left(p_{i}, \omega, p_{e}\right), m_{e}=f\left(p_{e}, h\right) .
$$

The final equation for the exhaust manifold is given by

$$
\tau_{e x} \frac{d p_{e}}{d t}+k_{e x} P_{e x}=N_{e}+a_{4} P_{i n}-b_{4} R
$$

where, $\quad \tau_{e x}=\frac{v_{e} \rho}{n_{r} \omega_{0}}\left(\frac{\delta m_{e e}}{\delta \omega}\right)^{-1}, \quad k_{e x}=F_{e x} \frac{p_{e e 0}}{\omega_{0}}\left(\frac{\delta m_{e e}}{\delta \omega}\right)^{-1}$,

$$
a_{4}=\frac{\delta m_{e e}}{\delta p_{i}} \frac{p_{i 0}}{\omega_{0}}\left(\frac{\delta m_{e e}}{\delta \omega}\right)^{-1}, b_{4}=\frac{\delta m_{e e}}{\delta h}\left(\frac{\delta m_{e e}}{\delta \omega}\right)^{-1} \frac{\delta \omega}{\omega_{0}} \text {. }
$$

\subsection{Governor}

A Proportional Integral Derivative (PID) control is used to provide the desired engine transient performance and to ensure that actual engine speed corresponds precisely to the desired speed at steady state. The PID controller law is expressed as

$$
R=k_{p} N_{e}+k_{i} \int N_{e} d t+k_{d} \frac{d N_{e}}{d t},
$$

where, $k_{p}, k_{i}, k_{d}$ are Proportional, Integral and Derivative control gains, respectively.

\section{OPTIMIZATION}

The system of differential equations for prime-mover (3.3), turbocharger (3.6), inlet manifold (3.8) and exhaust manifold (3.10) can be written in the determinant form to solve it for Ne using Cramer's Rule, so that,

$$
\Delta \cdot N_{e}=\Delta_{N_{e}} \Rightarrow N_{e}=\frac{\Delta_{N_{e}}}{\Delta}
$$


For most of the engines, inlet and exhaust manifold volumes are low and thus neglected, so that, $\tau_{e}$ and $\tau_{i n}$ are zero. Also when no supplementary air is injected, $Y_{s}$ is also zero. We finally get

$$
\Delta=\left|\begin{array}{cccc}
\left(\tau_{e} p+k_{e}\right) & -a_{1} & 0 & 0 \\
0 & a_{2} & \left(\tau_{t} p+k_{t}\right) & -1 \\
a_{3} & k_{i n} & -1 & 0 \\
-1 & -a_{4} & 0 & k_{e x}
\end{array}\right|
$$

and

$$
\Delta_{N_{e}}=\left|\begin{array}{cccc}
R-b_{1} L & -a_{1} & 0 & 0 \\
b_{2} R & a_{2} & \left(\tau_{t} p+k_{t}\right) & -1 \\
0 & k_{i n} & -1 & 0 \\
-b_{4} R & -a_{4} & 0 & k_{e x}
\end{array}\right|
$$

where, $p=\frac{d}{d t}$.

The expansion of determinants and their substitution into equation (4.1) gives

$$
T_{e 2}{ }^{2} \frac{d^{2} N_{e}}{d t^{2}}+T_{e 1} \frac{d N_{e}}{d t}+k_{e s} N_{e}=T_{R} \frac{d R}{d t}+k_{R} R-T_{L} \frac{d L}{d t}-k_{L} L
$$

where

$$
\begin{aligned}
& T_{e 2}^{2}=\tau_{e} \tau_{t} k_{i n} k_{e x} \\
& T_{e 1}=\left[\tau_{e}\left(k_{i n} k_{e x}+a_{1}\right)+\tau_{t}\left(k_{i n} k_{e}+a_{1} a_{3}\right)\right] k_{e x}-\tau_{e} a_{4} \\
& k_{e s}=k_{e} k_{e x}\left(k_{t} k_{i n}+a_{1}\right)-a_{1}\left(1-a_{3} k_{t} k_{e x}\right)-k_{e} a_{4} ; \\
& T_{R}=\tau_{t} k_{i n} k_{e x} ; \quad T_{L}=\tau_{t} k_{i n} k_{e x} b_{1} \\
& k_{R}=k_{e x}\left(k_{t} k_{i n}+a_{1} b_{2}+a_{2}\right)-b_{4} a_{1}-a_{4} ; \\
& k_{L}=b_{1} k_{e x}\left(k_{t} k_{i n}+a_{2}\right)-a_{4} b_{1} .
\end{aligned}
$$

Substituting for rack position, $R$ from equation (3.11) and $L=A_{1} \sin (\omega t)$ in above equation the equation is solved for $\mathrm{Ne}$ by taking Laplace and the inverse after due simplification, we get,

$$
N e=P+Q
$$

where,

$$
\begin{aligned}
P & =\frac{T_{L} A_{1}}{\alpha}\left[w\left(C-A w^{2}\right) \cos (w t) B w^{2} \sin (w t)\right. \\
& +w\left(C-A w^{2}\right)\left[\frac{\exp \left(-\xi w_{n} t\right)}{\sqrt{1-\xi^{2}}} \sin \left(w_{n} \sqrt{1-\xi^{2}} t-\tan ^{-1} \frac{\sqrt{\left(1-\xi^{2}\right)}}{\xi}\right)\right] \\
& \left.-\frac{B w w_{n}}{\sqrt{1-\xi^{2}}} \exp \left(-\xi w_{n} t\right) \sin \left(w_{n} \sqrt{1-\xi^{2}} t\right)\right]
\end{aligned}
$$




$$
\begin{aligned}
Q & =\frac{k_{L} A_{1} w}{A\left[\left(w_{n}^{2}-w^{2}\right)^{2}+\left(2 \xi w w_{n}\right)^{2}\right]}\left[-2 \xi w_{n} \cos (w t)\right. \\
& +\frac{w_{n}^{2}-w^{2}}{w} \sin (w t)+2 \xi w_{n} \exp \left(-\xi w_{n} t\right) \cos \left(w_{n} \sqrt{1-\xi^{2}} t\right) \\
& \left.+\frac{2 \xi^{2} w_{n}^{2}-\left(w_{n}^{2}-w^{2}\right)}{w_{n} \sqrt{1-\xi^{2}}} \exp \left(-\xi w_{n} t\right) \sin \left(w_{n} \sqrt{1-\xi^{2}} t\right)\right],
\end{aligned}
$$

and $A=T_{R} k_{d}-T_{e 2}^{2}, B=T_{R} k_{p}-T_{e 1}, C=T_{R} k_{i}-k_{e s}, w_{n}=\sqrt{C / A}$, $\xi=B / 2 \sqrt{A C}$.

In equation (4.3) the engine speed error $N_{e}$ is expressed in terms of the controller parameters $k_{p}, k_{i}, k_{d}$ and time $t$. The Integral Squared Error of engine speed is minimized using the FindMinimum command of the software Mathematica after integrating $N_{e}^{2}$ over the interval 0 to 5 seconds. i.e.,

$$
G=\int_{0}^{5} N_{e}^{2} d t=f\left(k_{p}, k_{i}, k_{d}\right) .
$$

The function $G$ is minimized to obtain the optimal controller parameters $k_{p}, k_{i}$, and $k_{d}$. After integrating $N_{e}{ }^{2}$ the resulting function $G$ contains the square roots of the following form

$$
\begin{aligned}
& \sqrt{\left(-2.33671+2.84237 k_{d}\right)\left(-8.62166+2.84237 k_{i}\right)}, \\
& \sqrt{\frac{-2.33671+2.84237 k_{d}}{-8.62166+2.84237 k_{i}}}, \\
& \sqrt{1-\frac{0.25 \cdot\left(53.5302+2.8437 k_{p}\right)^{2}}{\left(-2.33671+2.84237 k_{d}\right)\left(-8.62166+2.84237 k_{i}\right)}} .
\end{aligned}
$$

The constraints are obtained from these roots for the function $G$ to be real. First two roots yielded the following constraints $k_{i}>3.03326$ and $k_{d}>$ 0.822099 .

However from the third root, the quadratic condition is obtained. Thus the range of $k_{p}$ is obtained for various values of $k_{i}$ and $k_{d}$ for which the function is real. This exercise was done to know the values of realistic initial guesses.

From this exercise, initial guesses were tried as given in Tab. 1 and for each set of initial guesses of $k_{p}, k_{i}$ and $k_{d}$ optimal values are obtained using Mathematica.

\section{SIMULATION}

The simulation was done for the turbo charged diesel engine. The marine turbocharged, 6 cylinder engine model KTA-1150 C-600 of Kirloskar make has 
Table 1.

Initial Guesses and Optimal Parameters

\begin{tabular}{lrrrrrrr}
\hline Sr. & \multicolumn{3}{c}{ Initial Guesses } & \multicolumn{2}{c}{ Optimal Controller Parameters } & Function G \\
No. & $k_{p}$ & $k_{i}$ & $k_{d}$ & $k_{p}$ & $k_{i}$ & $k_{d}$ & \\
\hline 1. & 500 & 300 & 300 & 927.86 & 3.70 & 832.33 & $1.0710^{-17}$ \\
2. & 500 & 300 & 400 & 822.05 & 3.33 & 735.38 & $3.3910^{-18}$ \\
3. & 600 & 300 & 600 & 845.15 & 3.05 & 756.29 & $2.3210^{-20}$ \\
4. & 700 & 300 & 800 & 963.39 & 3.09 & 864.43 & $7.310^{-20}$ \\
5. & 700 & 300 & 900 & 1033.32 & 3.47 & 928.71 & $2.3210^{-18}$ \\
6. & 700 & 300 & 1000 & 1118.80 & 4.00 & 1007.38 & $7.9710^{-18}$ \\
7. & 800 & 300 & 1000 & 1117.38 & 3.10 & 1005.22 & $6.3310^{-20}$ \\
8. & 800 & 300 & 950 & 1080.08 & 3.04 & 971.079 & $2.510^{-21}$ \\
9. & 802.5 & 300 & 945 & 1076.96 & 3.04 & 968.22 & $5.1110^{-22}$ \\
10. & 900 & 300 & 1200 & 1288.71 & 3.09 & 1161.84 & $2.6610^{-20}$ \\
11. & 900 & 600 & 1200 & 1618.88 & 15.46 & 1482.92 & $1.510^{-16}$ \\
12. & 900 & 1100 & 1200 & 3052.89 & 18.5959 & 2781.92 & $1.6510^{-17}$ \\
\hline
\end{tabular}

been used for the simulation using MATLAB. Engine specifications are given in Appendix-1. The steady state experimental data [11], have been used to get torque $T_{e}$ as a function of rack position, inlet manifold pressure and engine speed. At a given torque, the values of $\delta T_{e} / \delta h, \delta T_{e} / \delta p_{i}, \delta T_{e} / \delta \omega$ are found by forward difference method using the instantaneous working conditions of $h, p_{i}, w$. The values $w_{0}, h_{0}, p_{i 0}, \phi_{0}$ are the steady state values. $\delta T_{t} / \delta \phi$ is assumed to be constant. It is assumed that compressor torque is equal to the turbine torque at steady state conditions.

To calculate the model coefficients, the steady state values of some parameters have been obtained from the engine data (torque-speed map, compressor map etc) received from the manufacturer and from the experiments carried out by [11].

Four basic equations derived for turbocharged diesel engine are used for this simulation along with load equation and rack control equation (3.11). The load equation used is $L=A_{1} \sin (\omega t)$

\section{RESULTS AND DISCUSSION}

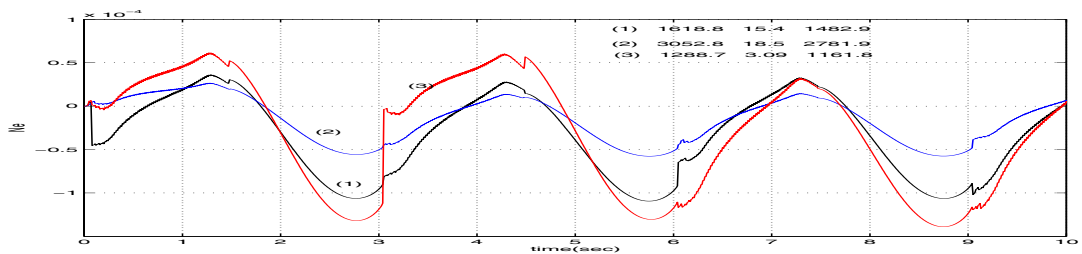

Figure 2. Speed Responses with Various sets of Optimized Parameters obtained with different Initial Guesses 


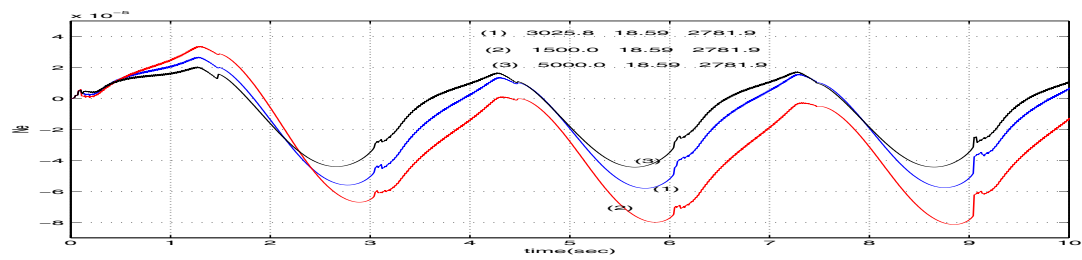

Figure 3. Effect of Variation of $k_{p}$ on the Speed Response

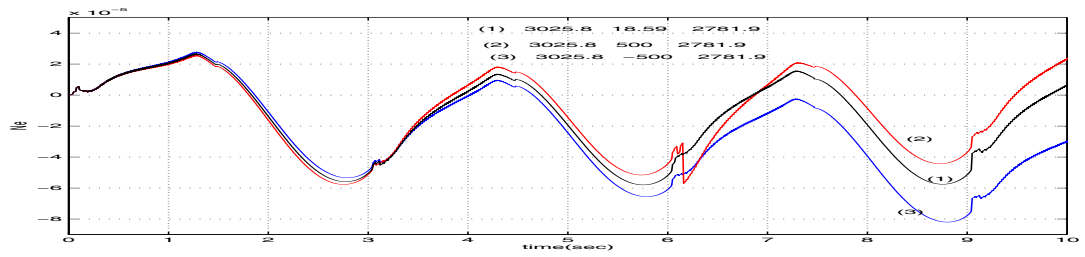

Figure 4. Effect of Variation of $k_{i}$ on the Speed Response

The optimum controller parameters obtained are used to plot the speed responses. Since, different optimum sets of controller parameters were obtained by varying initial guesses, it was necessary to select the best out of them (Tab. 1). The speed responses were obtained with each set of the optimum values. Fig. 2 shows speed responses with three characteristic sets. It is clear from the figure that the optimum set 12 in Tab. 1 (3052.89, 18.5959, 2781.92) gives the least speed fluctuations. Maximum fluctuation in the speed with this set of controller parameters is found to be $0.8510^{-4}$. Engine speed fluctuation corresponds to this is $0.102 \mathrm{rpm}$.

This set of parameters is further used to study the effect of variation of controller parameters on the speed response. Fig. 3 shows the effect of variation of $k_{p}$ on the speed response. Parameter $k_{p}$ was varied in steps of hundred and the effect was seen. It is found that the small change in $k_{p}$ has very little effect. Decrease in $k_{p}$ from 3025.8 to 1500 has resulted in noticeable deviation from the one with the optimum values. This deviation remained almost constant with time except for first few seconds. Rise in $k_{p}$ to 5000 has reduced steady state error.

Effect of variation of $k_{i}$ can be seen in Fig. 4. Increase in $k_{i}$ from its optimum value of 18.59 to 500 has proved to have increased the error in speed. The variation of $k_{i}$ with values in between 18.59 and 500 was also studied but results with significant effect are only presented. It is also observed that the steady state error increases continuously with the time. Decrease in $k_{i}$ from 18.59 to -500 has also resulted in increase in steady state error. Progressive increase in steady state error with time can be observed in this case also.

Effect of variation of frequency of load on the speed response has also been studied (see Fig. 5). The optimal controller parameters are used to plot the speed responses for this study. The speed responses are plotted with three 


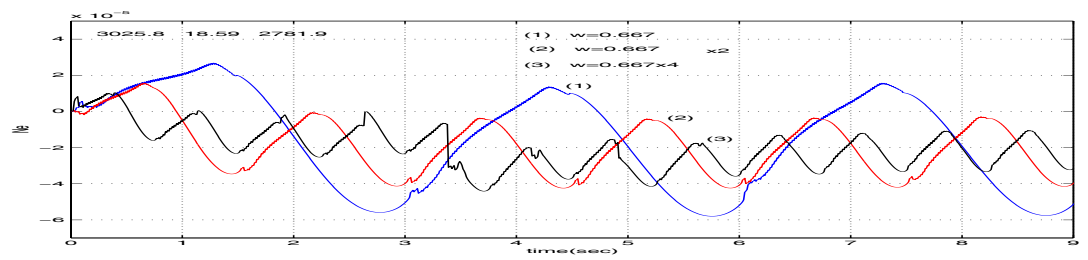

Figure 5. Effect of Variation of Load Frequency on Speed Response

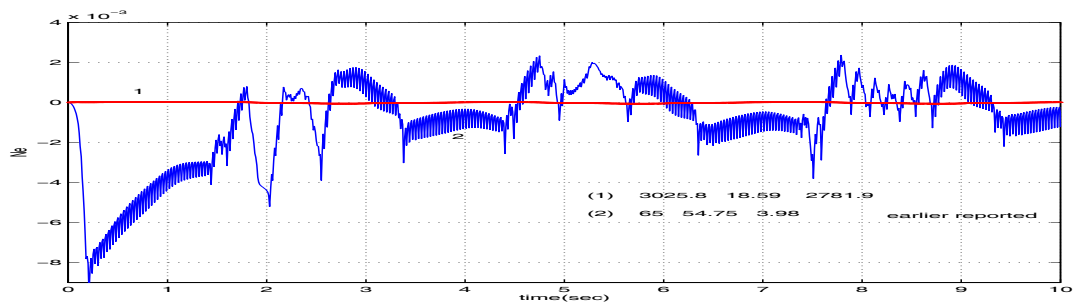

Figure 6. Comparison of Speed Responces by [8] with the Present Method

values of $\omega$ viz, $0.667,2 \times 0.667$ and $4 \times 0.667$. It is clear from the figure that the increase of frequency reduces the magnitude of speed fluctuation. It indicates that for the rapidly fluctuating loads same optimal parameters show better response.

Results obtained have been compared with the earlier studies reported [8] in Fig. 6 and Fig. 7. Reader is requested to note the scales used on $y$ axis. It is clear from the figure that the present method of optimizing the PID controller parameters $k_{p}, k_{i}$, and $k_{d}$ resulted in about 100 times lesser speed fluctuations as compared to the one obtained in [8], where the maximum speed fluctuation is $10.8 \mathrm{rpm}$ in comparison to $0.102 \mathrm{rpm}$ in present study.

\section{CONCLUSIONS}

Based on the present study, it can be concluded that,

1. Present method of Integral Squared Error has resulted in much better optimization of $k_{p}, k_{i}$ and $k_{d}$ values for minimum speed fluctuation of engine. The maximum speed fluctuation with optimum $k_{p}, k_{i}$ and $k_{d}$ values is 0.102 rpm in comparison with $10.8 \mathrm{rpm}$ in earlier study

2. Small changes in the value of $k_{p}$ and $k_{i}$ does not have significant effect on the speed fluctuations.

3. Large increase in $k_{p}$ reduces the steady state error.

4. Reduction in $k_{p}$ increases the steady state error. The resulting steady state error remains almost constant with time.

5 . With increase or decrease in $k_{i}$ the steady state error continuously increases with time. 

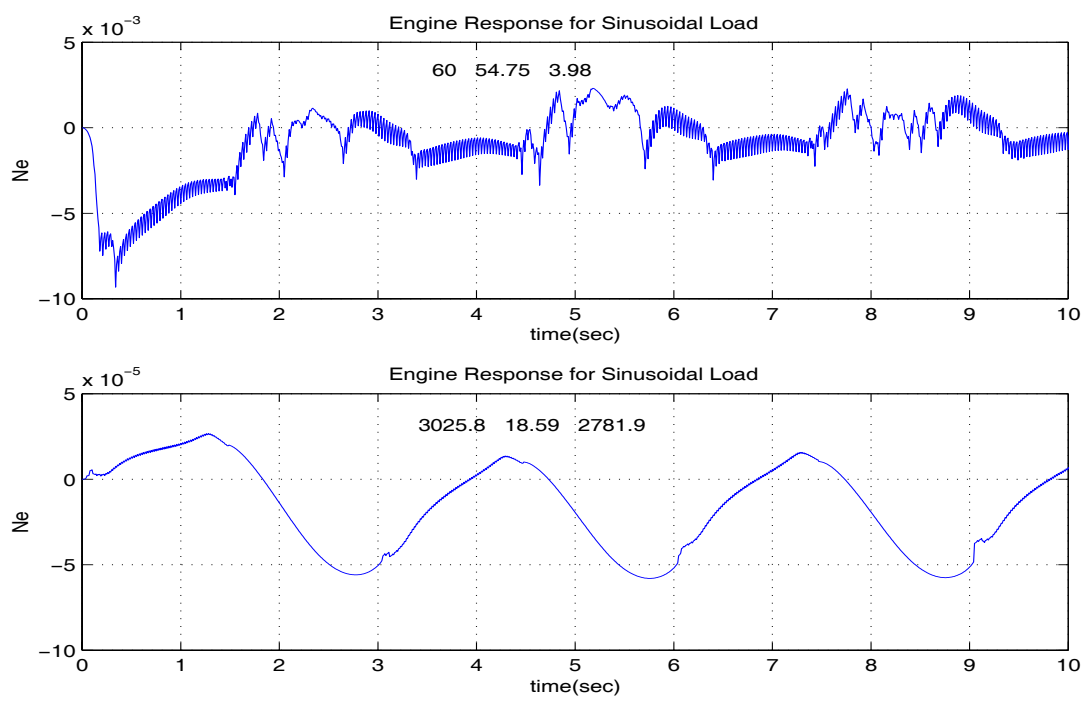

Figure 7. Comparison of Speed Responces by [8] with the Present Method

6. With increase in frequency the speed fluctuations decrease.

\section{APPENDIX}

8.1. Appendix 1 Engine Specifications

\begin{tabular}{ll}
\hline Parameter & Discription \\
\hline Model & KTA-1150 C-600 \\
Make & Kirloskar \\
Turbocharger & T 18 A \\
H.P. & 600 \\
Rated rpm & 2100 \\
No of cylinders & 6 \\
Bore $(\mathrm{mm})$ & 159 \\
Stroke $(\mathrm{mm})$ & 159 \\
\hline
\end{tabular}

8.2. Appendix 2 Data Used For Simulation

\begin{tabular}{lll}
\hline Thermodynamic & Geometrical & Ambient \\
\hline$\gamma=1.4$ & $v_{\text {in }}=0.1$ & $T_{0}=300$ \\
$\eta_{t}=0.7$ & $v_{e x}=0.075$ & $P_{\text {atm }}=10^{5}$ \\
$\eta_{c}=0.7$ & $J_{e}=27.5$ & $R=29.6$ \\
$c_{p}=1.004$ & $J_{t}=4 x 10^{-3}$ & \\
\hline
\end{tabular}




\subsection{Appendix 3 Nomenclatures Used}

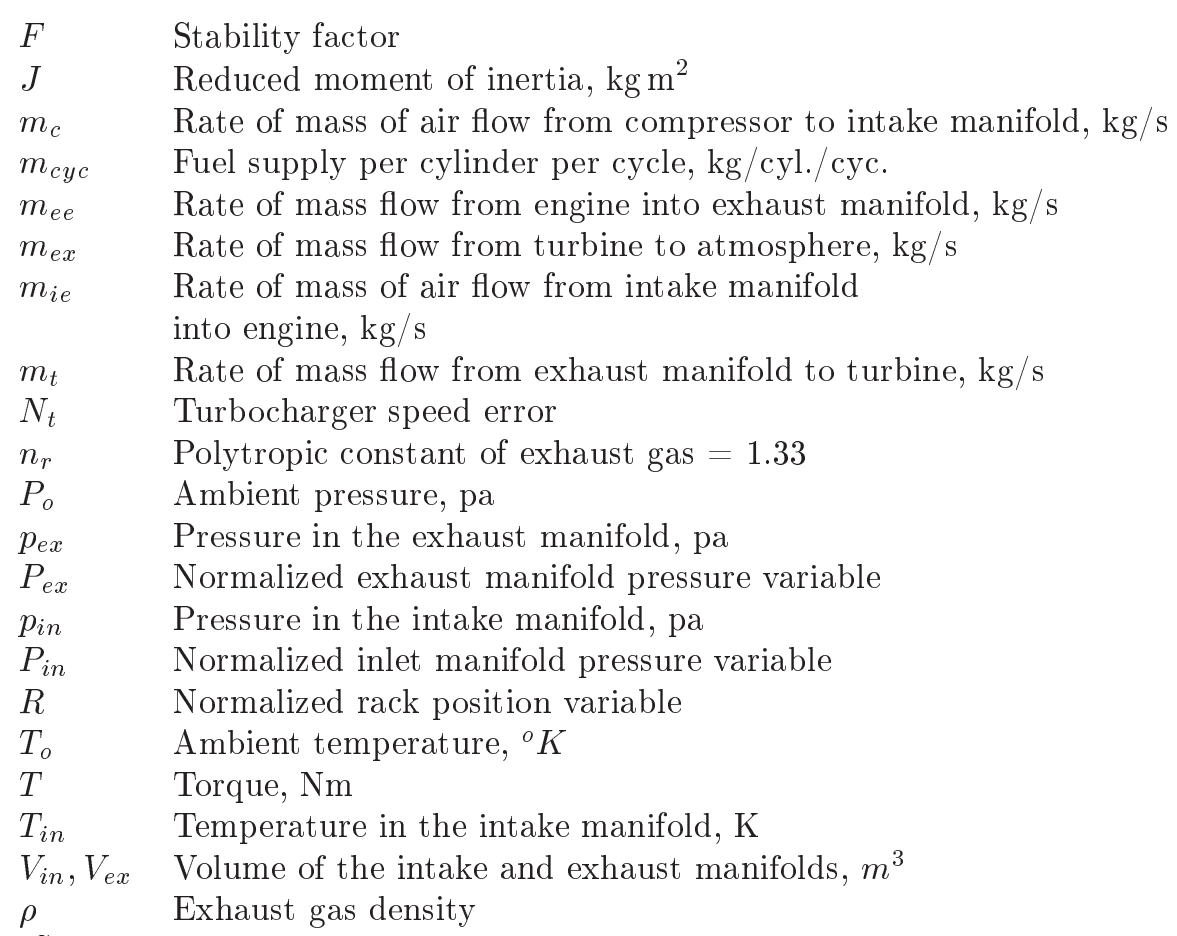

Subscripts $o, t, c, t c, e, l$, in and $e x$ denote subscripts used for steady state values, turbine, compressor, turbocharger, engine, load, inlet manifold and exhaust manifold, respectively.

\section{REFERENCES}

[1] Urs Christen, Katie J. Vantine and Nick Collings. Event-based Mean-value Modeling of DI Diesel Engines for Controller Design. In: SAE 2001 World Congress. Detroit, MI, USA, March 2001.

[2] H.C. Dhariwal, B.S. Chittawadgi and R.S. Bhatkokeshwar. Microprocessor based governing of diesel engines in mobile applications for best all round performance. In: 8th Int. Conference Churchill College, Cambridge University, England, 1984.

[3] Yousif Ali El-Imam. Simulation of a high-gain adaptive speed regulating system for an ic engine. Simulation, 39(4), 1982.

[4] J.O. Flower and R.K. Gupta. Optimal control considerations of diesel engine discrete models. Int. J. of Control, 19(6), 1057 - 1068, 1974.

[5] G. Hong and N. Collings. Design of diesel and smoke feedback control using a combination of pi algorithm and performance optimization sae. Tech. paper No. 890387 Optimal, 1989.

[6] S.A. Jaliwal, E. Day and W.H. Stahi. Diesel Engine Governing with Load Feedback. In: ASME Paper presented at Energy Source Technology Conference and Exhibition, Houston Texas, 1981.

[7] J. Jiang. Optimal gain scheduling controller for a diesel engine. IEEE Control System Magazine, 4, $42-48,1994$. 
[8] Y.K. Khurana. Some Investigations on Speed Control of Diesel Engines using PID Controller. M. Tech. Thesis, Indian Institute of Technology, Bombye, 2001.

[9] V.I. Krutov. Automatic Control of Internal Combustion Engines. Mir Publishers, Moscow, 1987.

[10] U. Mruthunjaya and H.C. Dhariwal. Investigation of control of speed of diesel engine using pid governor. SAE 2000-01-0264, SP-1500, 2001.

[11] R.P. Sinha. Some Investigations of Turbocharged diesel engines in Marine Engineering Applications. Ph. D. Thesis, Indian Institute of Technology, Bombay, 1988.

[12] C. Thiruarooran, Hoff Clausen N.E., Winterbone D.E. and Weistead P.E. The assessment and construction of models for transfer function evaluation of turbocharged diesel engines. Israel J. of Technology, 15, 1977.

[13] Shan-Chin Tsai and M.R. Goyal. Dynamic turbocharged diesel engine model for control analysis and design. SAE Paper No. 860455, 1986.

[14] N. Watson. Dynamic Turbocharged Diesel Engine Simulator for Engine Control System Development. ASME J. of Dynamic Systems, Measurement and Control, 1984.

[15] N. Watson and Marzouk Maged. A Non-linear Digital Simulation of Turbocharged Diesel Engine under Transient Conditions. SAE Paper 77012, 1977.

[16] D.E. Winterbone. Transient Response of Turbocharged Diesel Engines. SAE Paper No. 770122, 1977

[17] D.E. Winterbone. The Application of Modern Control Theory to a Turbocharged Diesel Engine powerplant. Proc. of IME, 205, 1991.

[18] J.B. Woodward and R.G. Lattore. Modeling of Diesel Engine Transient Behavior in Marine Propulsion Analysis. Society of Naval Architects and Marine Engineers. transactions, 92, $33-49,1984$.

\title{
Dizelinio variklio PID reguliatoriaus optimizavimas
}

\author{
D.N. Malkhede, H.C. Dhariwal, M.C. Joshi
}

Dizeliniame variklyje reguliatorius turi palaikyti nustatytą apsisukimų skaičių prie įvairių apkrovimo sąlygų, taip, kad variklio apsisukimų skaičius neviršytų tam tikros ribos, prie kurios variklis genda, arba užgęsta. Apsisukimu svyravimai sukelia vibraciją, triukšmą, nusidèvejjimą, ịplyšimus ir padidèja suodžiu kiekis. Todẻl pageidautina esant ịvairioms valdymo sąlygoms turèti minimalius apsisukimų skaičiaus svyravimus. Daugelis eksplotuojamų variklių, nepaisant nurodytụ trūkumų, naudoja paprastą mechaninį valdymą, atsižvelgiantį tik i proporcingus pokyčius. Šiame darbe turbokompresoriniam dizeliniam varikliui, panaudojus Krutovo analizès metodą sudarytas modelis, kuriame optimizuojami valdymo parametrai. Variklio apsisukimu skaičiaus svyravumu minimizavimui naudojama jų integralinès kvadratinès paklaidos analizè. Gauti parametrai panaudoti variklio reakcijai ị apsisukimų greitị nagrinèti. Rezultatai rodo žymų variklio apsisukimų skaičiaus svyravimų reguliavimo pagerinimą. 